PUBLIK: Jurnal Manajemen Sumber Daya Manusia, Administrasi dan Pelayanan Publik Sekolah Tinggi Ilmu Administrasi Bina Taruna Gorontalo Volume VI Nomor 2 Desember 2019

\title{
TRANSPARANSI KEPALA DESA DALAM PEMANFAATAN ALOKASI DANA DESA (ADD) DI DESA INOSOTA KECAMATAN POSIGADAN KABUPATEN BOLAANG MONGODOW SELATAN
}

\author{
Hasan Tamani ${ }^{1}$ \& Alfiyah Agussalim² \\ STIA Bina Taruna Gorontalo \\ bukujurnalstia@binataruna.ac.id ${ }^{1}$ \& $\underline{\text { alfiyahagussalim.a@gmail.com }}{ }^{2}$
}

\begin{abstract}
ABSTRAK
Penelitian ini bertujuan untuk mengetahui transparansi Kepala Desa dalam pemanfaatan Alokasi Dana Desa (ADD) di Desa Inosota Kecamatan Posigadan Kabupaten Bolaang Mongodow Selatan. Metode penelitian menggunakan jenis deskriptif pendekatan kualitatif. Teknik pengumpulan data dilakukan melalui wawancara mendalam kepada sejumlah informan, observasi dan pencatatan data sekunder yang berkaitan dengan permasalahan penelitian.

Hasil penelitian menyimpulkan bahwa, pelibatan masyarakat dalam pemanfaatan Alokasi Dana Desa (ADD) sudah dilakukan namun belum secara optimal. Hal ini terlihat dari kehadiran masyarakat yang hanya sebatas pendengar saja dan tidak diikutkan dalam pengambilan keputusan, dimana keputusan diambil secara sepihak oleh pemerintah desa atau Kepala Desa. Keterbukaan informasi publik dalam pemanfaatan Alokasi Dana Desa (ADD) sudah dilakukan namun belum secara optimal. Hal ini tampak dari tidak adanya kegiatan sosialisasi pemanfaatan Alokasi Dana Desa (ADD) yang dilakukan oleh Kepala Desa kepada masyarakat inosota secara keseluruhan. Pertanggungjawaban terbuka dalam pemanfaatan Alokasi Dana Desa (ADD) sudah dilakukan namun belum secara optimal. Hal ini tampak dari ketidaktahuan sebahagian besar masyarakat atas capaian kerja atau hasil pemanfaatan Alokasi Dana Desa (ADD). Disarankan, perlunya upaya seorang Kepala Desa Inosota untuk meningkatkan keterlibatan masyarakat dalam hal pemanfaatan Alokasi Dana Desa (ADD). Perlunya upaya seorang Kepala Desa Inosota untuk mewujudkan secara optimal keterbukaan informasi publik dalam hal pemanfaatan Alokasi Dana Desa (ADD). Perlunya upaya seorang Kepala Desa Inosota untuk melakukan pertanggungjawaban terbuka kepada masyarakat luas dalam hal pemanfaatan Alokasi Dana Desa (ADD)
\end{abstract}

Kata Kunci: Transparansi; Pemanfaatan; Alokasi Dana Desa

PENDAHULUAN

Pelaksanaan Alokasi Dana

Desa (ADD) diatur oleh pemerintah dalam PP Nomor 72 Tahun 2005 tentang Desa. Dalam pasal 68 ayat 1 huruf c, dijelaskan bahwa bagian dari dana perimbangan pusat dan daerah 
PUBLIK: Jurnal Manajemen Sumber Daya Manusia, Administrasi dan Pelayanan Publik Sekolah Tinggi Ilmu Administrasi Bina Taruna Gorontalo Volume VI Nomor 2 Desember 2019

yang diterima oleh kabupaten/kota untuk desa paling sedikit $10 \%$ yang pembagiannya untuk setiap desa secara proporsional yang merupakan ADD. Peraturan mengenai ADD ditindak lanjuti melalui Surat Edaran Menteri Dalam Negeri Nomor 140/640/SJ Tahun 2005 tentang Pedoman ADD dari Pemerintah Kabupaten/Kota kepada Pemerintah Desa yang intinya berisi mengenai prosedur pelaksanaan Alokasi Dana Desa.

Berkenaan engan filosofi Dana
Desa adalah
kesejahteraan dan
pembangunan pemerataan
peningkatan pelayanan publik desa,
memajukan perekonomian desa,
mengatasi kesenjangan pembangunan antara desa serta memperkuat masyarakat desa sebagai subjek dari pembangunan. sesuai dengan UndangUndang Nomor 6 Tahun 2014 tentang desa maka desa diberikan keleluasaan untuk mengatur kewenangannya, baik kewenangan berdasarkan hak asal usul, kewenangan ditugaskan pemerintah dan kewenagan lain yang ditugaskan Pemerintah sesuai tugas.

Dalam rangka melaksanakan kewenangan tersebut, desa diberi sumber-sumber pendapatan asli desa yaitu (hasil usaha, hasil aset, swadaya dan partisipasi, gotong royong, dan lain-lain). Kewenang desa diatur dalam UU Nomor 6 Tahun 2014 Bab IV pasal 19 yang dimana meliputi kewenangan berdasarkan asal usul, kewenangan lokal berskala desa, kewenagan yang ditugaskan oleh pemerintah daerah provinsi, atau pemerintah daerah kabupaten/kota.
Kondisi masyarakat desa sekarang ini perlu perubahan yang mendasar agar segenap anggota masyarakat dapat mandiri, percaya diri, tidak bergantung dan dapat lepas dari belenggu struktural yang membuat kehidupannya mengalami kesenjangan sosial seiring dengan gencarnya otonomi desa, regulasi tentang desa tidak hanya mengatur tentang pemerintah desa baik itu kepala desa, perangkat desa ataupun BPD tetapi bagaimana implementasi dari tugas pokok dan fungsi untuk pembangunan masyarakat. Lembaga kemasyarakatan di desa tidak hanya diberi pengaturan tentang tugas pokok dan fungsi dan organisasinya tetapi perlu didukung dalam segi dana untuk oprasional kegiatan baik itu dari pemerintah desa melalui program Dana Desa.

Pemerintah telah menetapkan Peraturan Pemerintah Nomor 60 Tahun 2014 tentang Dana Desa yang bersumber dari APBN sebagaimana telah dirubah dengan Peraturan Pemerintah Nomor 22 Tahun 2015. Pokok-pokok pengaturan dalam Peraturan Pemerintah tersebut, antara lain, mengenai mekanisme pengalokasian dan penyaluran Dana Desa, penggunaan dan pelaporan Dana Desa, monitoring dan evaluasi Dana Desa serta roadmap Dana Desa.

Oleh sebab itu dalam pelaksanaannya, ADD harus betulbetul bisa dimanfaatkan secaja bijak oleh pemerintah desa sehingga bisa dinikmati oleh seluruh warga desa. Dalam pemanfaatannya, Kepala Desa sebagai pelaksana sekaligus penanggungjawab dari pengelolaan 
ADD harus mampu mengemban tugasnya dengan mengedapankan prinsip keterbukaan ataupun transparansi. Transparansi sendiri merupakan ciri yang melekat bagi sebuah daerah atau pemerintahan yang bersih dan modern. Banyaknya Desa yang mengalami kegagalan dalam mengelola ADD, salah satunya disebabkan oleh ketidakterbukaan pemerintah desa dalam mengelola keuangan desa.

Demikian halnya dengan pengelolaan ADD yang ada di Desa Inosota Kecamatan Posigadan, dimana sejauh ini masyarakat belum merasakan secara optimal hasil dari ADD. Hal ini tidak terlepas dari sikap Kepala Desa di dalam mengelola ADD yang cenderung tertutup. Dan berdasarkan hasil observasi menunjukkan bahwa Kepala Desa dalam mengelola ADD belum melibatkan masyarakat secara penuh. Hal ini dapat terlihat dari minimnya jumlah partisipasi masyarakat dalam rapat-rapat Desa ataupun dalam kegiatan Musyawarah Perencanaan Pembangunan (Musrenbang).

Selanjutnya, Kepala Desa juga belum menerapkan keterbukaan informasi publik terkait dengan pemanfaatan ADD. Hal ini terlihat dari ketiadaan papan informasi desa yang merupakan media sumber informasi bagi masyarakat desa sehingga masyarakat bisa mengukur sejauh mana ADD telah dipergunakan. Selain itu, Kepala Desa juga tidak melakukan pertanggungjawaban secara terbuka kepada masyarakat terkait dengan pengelolaan $\mathrm{ADD}$, kemana dan apa saja wujud dari pelaksanaan ADD. Hal ini berdampak pada ketidaktahuan masyarakat atas hasil capaian dari pemanfaatan ADD.

Berdasarkan uraian tersebut, maka perlu dilakukan penelitian lebih dalam untuk mendapatkan gambaran yang lebih jelas dengan judul "Transparansi Kepala Desa dalam Pemanfaatan Alokasi Dana Desa (ADD) di Desa Inosota Kecamatan Posigadan Kabupaten Bolaang Mongodow Selatan".

\section{PERMASALAHAN}

Adapun rumusan masalah penelitian ini adalah bagaimana Transparansi Kepala Desa dalam pemanfaatan Alokasi Dana Desa (ADD) di Desa Inosota Kecamatan Posigadan Kabupaten Bolaang Mongodow Selatan?

\section{Tujuan Penelitian}

Berdasarkan rumusan masalah di atas, maka tujuan penelitian ini adalah untuk mengetahui Transparansi Kepala Desa dalam pemanfaatan Alokasi Dana Desa (ADD) di Desa Inosota Kecamatan Posigadan Kabupaten Bolaang Mongodow Selatan.

\section{Fokus Penelitian}

Adapun fokus penelitian mengenai Transparansi Kepala Desa Dalam Pemenfaatan Alokasi Dana Desa di Desa Inosota Kecamatan Posigadan Kabupaten Bolaang Mengondow adalah meliputi: 
Pelibatan Masyarakat

Pelibatan masyarakat yang

dimaksudkan dalam penelitian ini adalah upaya perwujudan prinsip transparansi pemanfaatan Alokasi Dana yang dilakukan oleh Kepala Desa dengan melibatkan unsur masyarakat dalam perencanaan pengalokasian dana desa.

\section{Keterbukaan Informasi Publik}

Keterbukaan informasi publik yang dimaksudkan dalam penelitian ini adalah upaya perwujudan prinsip transparansi pemanfaatan Alokasi Dana yang dilakukan oleh Kepala Desa dengan memberikan informasi kepada masyarakat terkait dengan pemanfaatan ADD.

\section{Pertanggungjawaban Terbuka}

Pertanggungjawaban yang dimaksudkan dalam penelitian ini adalah upaya perwujudan prinsip transparansi pemanfaatan Alokasi Dana yang dilakukan oleh Kepala Desa dengan melakukan pertanggungjawaban di depan masyarakat atas capaian pelaksanaan pengalokasian dana desa.

\section{METODE PENELITIAN}

\section{Jenis Penelitian}

Jenis penelitian ini adalah penelitian deskriptif metode kualitatif. Sumber data berasal dari data primer dan data sekunder. Teknik pengumpulan data dilakukan melalui observasi, wawancara dan dokumentasi. Sedangkan teknik analisis data mengacu pada pendapat Miles dan Huberman (dalam Sugiyono, 2013:337), yaitu melalui
Reduksi data, Penyajian data, dan Verifikasi.

\section{HASIL PENELITIAN DAN PEMBAHASAN}

Makna dari transparansi dalam penyelenggaraan pemerintahan daerah dapat dilihat dalam dua hal yaitu: (1) salah satu wujud pertanggung jawaban pemerintah kepada rakyat, dan (2) upaya peningkatan manajemen pengelolaan dan penyelenggaraan pemerintahan yang baik dan mengurangi kesempatan praktek kolusi, korupsi dan nepotisme (KKN). Transparansi sebagai penyediaan informasi tentang pemerintahan bagi publik dan dijaminnya kemudahan di dalam memperoleh informasiinformasi yang akurat dan memadai. Dari pengertian tersebut dijelaskan bahwa transparansi tidak hanya sekedar menyediakan informasi tentang penyelenggaraan pemerintahan, namun harus disertai dengan kemudahan bagi masyarakat untuk memperoleh informasi tersebut.

Dalam penelitian ini, terdapat tiga indikator yang dapat digunakan untuk mengukur tingkat transparansi penyelenggaraan pemerintahan khususnya tentang transparansi Kepala Desa dalam pemanfaatan ADD di Desa Inosota Kecamatan Posigadan Kabupaten Bolaang Mongodow Selatan, yaitu; pelibatan masyarakat, keterbukaan informasi publik dan pertanggungjawaban terbuka.

Berikut adalah uraian pembahasan tentang transparansi Kepala Desa dalam pemanfaatan ADD 
PUBLIK: Jurnal Manajemen Sumber Daya Manusia, Administrasi dan Pelayanan Publik Sekolah Tinggi Ilmu Administrasi Bina Taruna Gorontalo Volume VI Nomor 2 Desember 2019

di Desa Inosota Kecamatan Posigadan Kabupaten Bolaang Mongodow Selatan.

Salah satu karakteristik dari good governance atau tata kelola pemerintahan yang baik atau kepemerintahan yang baik adalah partisipasi. Bahkan Isbandi Rukminto Adi (2009) menyatakan untuk menciptakan partisipasi aktif masyarakat dalam melaksanakan program pembangunan diperlukan kesadaran warga masyarakat akan minat dan kepentingan yang sama. Strategi yang dapat diterapkan adalah penyadaran. Untuk berhasilnya program tersebut warga masyarakat dituntut untuk terlibat tidak hanya dalam aspek kognitif dan praktis tetapi juga keterlibatan emosional.

Adapun pelibatan masyarakat yang dimaksud dalam penelitian ini adalah upaya perwujudan prinsip transparansi pemanfaatan Alokasi Dana yang dilakukan oleh Kepala Desa dengan melibatkan unsur masyarakat dalam perencanaan pengalokasian dana desa. Berdasarkan hasil penelitian dan analisis penulis dapat diketahui bahwa pelibatan masyarakat dalam pemanfaatan ADD sudah dilakukan namun belum secara optimal. Hal ini terlihat dari kehadiran masyarakat yang hanya sebatas pendengar saja dan tidak diikutkan dalam pengambilan keputusan, dimana keputusan diambil secara sepihak oleh pemerintah desa atau Kepala Desa.

Untuk mewujudkan penyelenggaraan pemerintahan yang transparan dan akuntabel, baik badan publik di tingkat pusat maupun daerah dituntut untuk berkomitmen tinggi dalam melaksanakan undang-undang ini demi terciptanya praktik demokratisasi dan good governance. Karena pada dasarnya, konteks lahirnya UU Keterbukaan Informasi Publik (KIP) ini secara substansial bertujuan untuk memberikan jaminan konstitusional agar praktik demokratisasi dan good governance bermakna bagi proses pengambilan kebijakan terkait kepentingan publik, yang bertumpu pada partisipasi masyarakat maupun akuntabilitas lembaga penyelenggara kebutuhan publik.

Dalam penelitian ini kemudian ditafsirkan bahwa, keterbukaan informasi publik adalah upaya perwujudan prinsip transparansi pemanfaatan ADD yang dilakukan oleh Kepala Desa dengan memberikan informasi kepada masyarakat terkait dengan pemanfaatan ADD. Berdasarkan hasil penelitian dan analisis dapat diketahui bahwa keterbukaan informasi publik dalam pemanfaatan ADD sudah dilakukan namun belum secara optimal. Hal ini tampak dari tidak adanya kegiatan sosialisasi pemanfaatan ADD yang dilakukan oleh Kepala Desa kepada masyarakat inosota secara keseluruhan.

Untuk menilai suatu program berhasil atau tidak maka yang menjadi acuannya adalah capaian hasil kerja program. Capain hasil kerja biasanya dilaporkan baik dalam bentuk tertulis maupun dalam bentuk lisan atau penjelasan secara langsung. Laporan 
atas capaian hasil kerja inilah yang disebut dengan pertanggungjawaban.

Pertanggungjawaban merupakan kesadaran manusia akan tingkah laku atau perbuatan yang disengaja maupun yang tidak disengaja. Tanggung jawab juga berarti berbuat sebagai perwujudan kesadaran akan kewajibannya. Tanggung jawab itu bersifat kodrati, artinya sudah menjadi bagian kehidupan manusia, bahwa setiap manusia pasti dibebani dengan tanggung jawab.

Dalam penelitian ini, yang dimaksudkan dengan pertanggungjawaban terbuka adalah upaya perwujudan prinsip transparansi pemanfaatan Alokasi Dana yang dilakukan oleh Kepala Desa dengan melakukan pertanggungjawaban di depan masyarakat atas capaian pelaksanaan pengalokasian dana desa. Berdasarkan hasil penelitian dan analisis dapat diketahui bahwa pertanggungjawaban terbuka dalam pemanfaatan ADD sudah dilakukan namun belum secara optimal. Hal ini tampak dari ketidaktahuan sebahagian besar masyarakat atas capaian kerja atau hasil pemanfaatan ADD.

Secara keseluruhan dapat disimpulkan bahwa transparansi Kepala Desa dalam pemanfaatan ADD di Desa Inosota Kecamatan Posigadan Kabupaten Bolaang Mongodow Selatan belum optimal. Hal tersebut dikarenakan belum optimalnya pelibatan masyarakat di dalam pemanfaatan ADD, kurangnya keterbukaan informasi publik, dan masih rendahnya pertanggungjawaban

terbuka Kepala Desa dalam

pemanfaatan ADD.

\section{SIMPULAN}

Berdasarkan hasil penelitian dan pembahasan, maka dapat disimpulkan sebagai berikut:

1. Pelibatan masyarakat dalam pemanfaatan ADD sudah dilakukan namun belum secara optimal. Hal ini terlihat dari kehadiran masyarakat yang hanya sebatas pendengar saja dan tidak diikutkan dalam pengambilan keputusan, dimana keputusan diambil secara sepihak oleh pemerintah desa atau Kepala Desa.

2. Keterbukaan informasi publik dalam pemanfaatan ADD sudah dilakukan namun belum secara optimal. Hal ini tampak dari tidak adanya kegiatan sosialisasi pemanfaatan ADD yang dilakukan oleh Kepala Desa kepada masyarakat Inosota secara keseluruhan.

3. Pertanggungjawaban terbuka dalam pemanfaatan ADD sudah dilakukan namun belum secara optimal. Hal ini tampak dari ketidaktahuan sebahagian besar masyarakat atas capaian kerja atau hasil pemanfaatan ADD.

4. Secara keseluruhan dapat disimpulkan bahwa transparansi Kepala Desa dalam pemanfaatan ADD di Desa Inosota Kecamatan Posigadan Kabupaten Bolaang Mongodow Selatan belum optimal. Hal tersebut dikarenakan belum 
PUBLIK: Jurnal Manajemen Sumber Daya Manusia, Administrasi dan Pelayanan Publik Sekolah Tinggi Ilmu Administrasi Bina Taruna Gorontalo Volume VI Nomor 2 Desember 2019

optimalnya pelibatan masyarakat di dalam pemanfaatan ADD, kurangnya keterbukaan informasi publik, dan masih rendahnya pertanggungjawaban terbuka Kepala Desa dalam pemanfaatan ADD.

\section{SARAN}

Berdasarkan simpulan tersebut, maka dapat disarankan:

1. Perlunya upaya seorang Kepala Desa Inosota untuk meningkatkan keterlibatan masyarakat dalam hal pemanfaatan ADD.

2. Perlunya upaya seorang Kepala Desa Inosota untuk mewujudkan secara optimal keterbukaan informasi publik dalam hal pemanfaatan ADD.

3. Perlunya upaya seorang Kepala Desa Inosota untuk melakukan pertanggungjawaban terbuka kepada masyarakat luas dalam hal pemanfaatan ADD.

4. Perlunya dilakukan upaya yang menyeluruh dalam menerapkan transparansi pemanfaatan ADD dengan mengoptimalkan keterlibatan masyarakat, keterbukaan informasi publik, dan pertanggungjawaban terbuka.

\section{DAFTAR PUSTAKA}

Alex Sobur. 2010. Psikologi Umum Dalam Lintasan Sejarah. Jakarta: Pustaka Setia.

A.M. Sardiman. 2007. Interaksi dan Motivasi Belajar Mengajar. Bandung: Rajawali Pers
Abdul Aziz, Thohir 2009. Etika Bekerja Dalam Islam. Jakarta: Gema Insani Press.

Andi, 2009. Membangun Aplikasi Bisnis Dengan Netbeans 7. Yogyakarta: Wahana Komputer.

Arikunto, Suharsimi. 2009. Prosedur Penelitian: Suatu Pendekatan Praktek. Jakarta: Rineka Cipta.

Arikunto, Suharsimi, 2009. Manajemen Perbankan. Jakarta: Gunung Agung.

Atmodowirdjo, 2006. Peran Disiplin Pada Perilaku dan Prestasi Siswa. Jakarta: Grasindo.

Azwar, Saifuddin, 2010. Penyusunan Skala Psikologi. Yogyakarta: Pustaka Pelajar,

Fathoni, Abdurrahmat DV, 2006. Organisasi dan Manajemen Sumber Daya Manusia. Bandung: PT. Rineka Cipta.

Hasibuan, Malayu. 2008. Manajemen Sumber Daya Manusia. Edisi Revisi. Jakarta: PT. Bumi Aksara.

Hasibuan, Malayu, 2005. Manajemen Sumber Daya Manusia, Edisi Revisi. Jakarta: Bumi Aksara.

Heri Purwanto, 2010. Pengantar Perilaku Manusia. Jakarta: EGC.

Mardiyanto, 2008. Kewirausahaan. Surakarta: Yudhistira

Masong, 2011. Etos Kerja Islam. Jakarta: Pedoman Ilmu Jaya.

Musanef. 2004. Manajemen Kepegawaian di Indonesia. Cetakan ke-2. Jakarta: PT. Gunung Agung.

Notoatmodjo, S. 2007. Promosi Kesehatan dan Ilmu Perilaku. Jakarta: Rineka Cipta. 
Sinamo Jansen, 2007. Etos Kerja

Profesional di Era Digital

Global, Ed 1. Jakarta: Institut

Darma Mahardika.

Siswanto, Bedjo. 2001. Manajemen

Tenaga Kerja, Rancangan

Dalam Pendayagunaan dan

Pengembangan Unsur Tenaga

Kerja. Bandung: Sinar Baru

Sugiyono. 2010. Metode Penelitian

Kuantitatif Kualitatif dan

$R \& D$, Ed. Revisi Cet. Ke -10,

Bandung: CV. Alfabeta.

Suryana. 2006. Kewirausahaan:

Pedoman Praktis, Kiat dan

Proses Menuju Sukses. Jakarta:

Salemba Empat

Toto Tasmara, 2010. Etos Kerja

Pribadi Muslim. Yogyakarta:

PT. Dana Bhakti Wakaf.

Wahid Iqbal, dkk. 2006. Ilmu Keperawatan Komunitas.

Jakarta: CV Sagung Seto.

Widjaja.2010. Otonomi Desa. Jakarta:

Raja Grafindo Persada.

Wirartha, I Made. 2006. Metode

Penelitian Sosial Ekonomi.

Yogyakarta: PT. Andi Offset.

\section{Dokumen Lain;}

Undang-Undang Dasar 1945 alinea IV. Undang-Undang No. 23 Tahun 2014

tentang Pemerintahan Daerah

UU Nomor 12 Tahun 2008 tentang Pemerintahan Daerah

Undang-Undang Nomor 32 Tahun 2004 tentang Pemerintahan Daerah

Peraturan Pemerintah Nomor 41

Tahun 2007 tentang Organisasi

Perangkat Daerah 